\title{
Technologic Tests of Turkey-Gordes Zeolite Minerals
}

\author{
Oyku Bilgin \\ Department of Mining Engineering, Sirnak University, Sirnak, Turkey \\ Email: ykbilgin@yahoo.com
}

How to cite this paper: Bilgin, O. (2017) Technologic Tests of Turkey-Gordes Zeolite Minerals. Journal of Minerals and Materials Characterization and Engineering, 5, 252-265.

https://doi.org/10.4236/jmmce.2017.55021

Received: February 23, 2017

Accepted: August 11, 2017

Published: August 14, 2017

Copyright $\odot 2017$ by author and Scientific Research Publishing Inc. This work is licensed under the Creative Commons Attribution International License (CC BY 4.0).

http://creativecommons.org/licenses/by/4.0/ (c) (i) Open Access

\begin{abstract}
Natural zeolites are found at many points of the world in the form of minerals. As for Turkey, quite large volumes of zeolites reserves are available in the following regions: Ankara (Nallihan, Beypazari, Polatli etc.), Kütahya-Saphane, Manisa-Gördes, Manisa-Demirci, Izmir-Urla, Balıkesir-Bigadiç and Cappadocia. By means of the works carried out only at the field in BalikesirBigadiç region, one of the detected reserves in Turkey, it was understood that an easily workable potential around 500 million ton is available. According to the very limited observations made until today, it is stated that the total reserve in our country may be around 500 billion ton. In these regions, the types of clinoptilolite, hoylandit, chabazite, analcime and erionite from the zeolite minerals exist. Zeolites are widely used in many sectors such as energy, environment, construction, detergent, chemistry, medicine, mining, agriculture and livestock. Zeolites also provide great benefits when they are used especially in agriculture and livestock for the purpose of preventing environmental pollution threatening human being. In this study, zeolite sample taken from Manisa-Gördes region was used. Following the processes of crushing and sieving, zeolite sample was subjected to chemical analyses according to their grain thickness, microscopic examination, the analyses of XRD and Technological Tests (ceramic pre-technological reviews, value of oil absorption, whiteness measurements, examination of the zeolite sample as cat litter, determination of bleaching capability, porosity values) and their ore characteristics were determined. After the analyses, ferrous oxide, biotite, quartz, muscovite, feldspar, chlorite, non-zeolite silicates and metamorphic rock fragments have been found. This zeolite mineral with high mineral purity has been suggested to clear off all impurities via ore preparation and enrichment methods.
\end{abstract}

\section{Keywords}

Technological Tests, Zeolite, Clinoptilolite, Chemical Analysis 


\section{Introduction}

Zeolite is a word meaning "Fusing Rock". It earned this name because of its ability to explode and disintegrate when it is heated. Zeolite was first discovered in 1856 by Swedish mineralogist Freiherr Axel Fredrick Cronstedt. Zeolites are a mineral group that is formed by the change of volcanic ash in aquatic environment millions of years ago, comprising alkali and alkaline-earth hydrated natural silicates. Zeolitization is a process in which feldspar and other aluminosilicates turn into zeolites. Zeolite minerals are in an aluminosilicate structure which is comprised of connected tetrahedral $\mathrm{AlO}_{4}$ and $\mathrm{SiO}_{4}$ via sharing oxygen atoms and can grow infinitely as a three dimensional web. Their structure is similar to honey combs or cages and includes alterable cations and water. Micro foramens between the units merge in micro windows and form one, two or three dimensional clearance systems and canals. The amount of clearance is between $20 \%$ and $50 \%$ of the total volume. These channels and cages are adequate for adsorbing molecules smaller than these channels and/or tunnels, so in this regard, zeolites are known as "molecular sieves" [1] [2] [3].

One of the main properties of zeolites is its canals (pores), which have a homogenous structure in crystal form. Zeolites have ion exchange, absorption, molecular sifting and catalytical effect mechanisms because of these [4] [5] [6] [7] [8]. Zeolite skeleton is formed by the open crystal cage wave formation of different shapes of $\mathrm{SiO}_{4}$ and $\mathrm{AlO}_{4}$ tetrahedras. Its micro canal structure is formed by its crystal cage structure, which contains canals on a molecular scale [6] [7].

There are more than 40 known minerals. The most important of these are clinoptilolite, heulandite and chabazite. With its chemical formula of $(\mathrm{Na}, \mathrm{K})_{6}\left(\mathrm{Al}_{6} \mathrm{Si}_{30} \mathrm{O}_{72}\right) \cdot 20 \mathrm{H}_{2} \mathrm{O}$, clinoptilolite's crystal system is monoclinic, and its competence in silicates class is 3.5 - 4, and its specific gravity is 2.2. It is vitreous, neat, transparent or semi-transparent. It can be colourless, white, pink, yellow or have a reddish hue. It is resistant to heat. Its $\mathrm{Si} / \mathrm{Al}$ mol ratio is $0.425 / 5.25$. It is a resistant zeolite to acid (pH: 1.5 - 11). Its crystal clearance is $39 \%$. Its most important feature is its canal shaped clearance structures. Its water, oil and gas absorption capacity is relatively high. Clinoptilolite is formed via the transformation of volcanic glass and tuff into crystal materials with the effect of heat. Volcanic rocks form with basalt, rhyolite and andesite and with borate minerals in deep seas as residuum.

Clinoptilolite and heulandite are very similar in terms of their crystal structure and they cannot be distinguished from each other, even in X-Ray images. Both zeolite minerals are formed in a layered structure, tectosilicate sub class and their oxygen atoms are covered by silica or aluminium ions. Layers are formed by 8 - 10 edged open rings and layers are piled together and form canals and clearance within the crystal. Canals work like a molecular sieve because of their ability to allow certain molecules and deny certain others according to 
their sizes. Clinoptilolite's difference from heulandite is its relative richness of silica and the fact that it is more resistant to heat. For example, heulandite transforms to another phase which is named as heulandite $\mathrm{B}$ in $230^{\circ} \mathrm{C}$ and becomes completely amorphous in $350^{\circ} \mathrm{C}$. Clinoptilolite retains its crystal formation up to $700^{\circ} \mathrm{C}$. It is heulandite if the $(\mathrm{Na}+\mathrm{K}) /(\mathrm{Na}+\mathrm{K}+\mathrm{Mg}+\mathrm{Ca})$ ratio is bigger than 0.5; otherwise it is clinoptilolite [9] [10]; or it is clinoptilolite if the $(\mathrm{Na}+\mathrm{K}) /(\mathrm{Mg}+\mathrm{Ca})$ ratio is bigger than 0.69 ; otherwise it is heulandite [11]. It is clinoptilolite if the $\mathrm{Si} / \mathrm{Al}$ ratio per cell is bigger than 4; otherwise it is heulandite [12].

Manisa-Gordes zeolites are in the structure of potassium, calcium clinoptilotite in high thermal stability and have a specific gravity between $1.98-2.18$ $\mathrm{g} / \mathrm{cm}^{3}$. Bulk density varies according to granule bulk between $0.693-1.22$ $\mathrm{g} / \mathrm{cm}^{3}$. The specific surface area of Gordes zeolites is $40.80 \mathrm{~m}^{2} / \mathrm{g}$. Gordes zeolites release their foramen water in $50^{\circ} \mathrm{C}-90^{\circ} \mathrm{C}$, bound-water at $90^{\circ} \mathrm{C}-320^{\circ} \mathrm{C}$, crystal water at $360^{\circ} \mathrm{C}-770^{\circ} \mathrm{C}$ and their structure begins to dissolve at $839^{\circ} \mathrm{C}$. Thermal stability endures up to $1000^{\circ} \mathrm{C}$. The water absorption capacity of Gordes zeolites is between 15\% - 30\%. Gordes zeolites have high thermal stability and their natural unit bulk weight is $1.36 \mathrm{~g} / \mathrm{cm}^{3}$. Rock form Gordes zeolites has $0.418-0.477 \mathrm{~W} / \mathrm{m}^{\circ} \mathrm{C}$ of transmission coefficient. Meanwhile with the classified granule size, this changes to $0.098-0.273 \mathrm{~W} / \mathrm{m}^{\circ} \mathrm{C}$. In mercury and vanadium adsorption studies, 1 gram of zeolite absorbed $0.310 \mathrm{mg}$ vanadium and $2.841 \mathrm{mg}$ mercury [13]. The structural features of Gordes clinoptilolites are presented in Table 1.

\section{Geology of Manisa-Gordes Region}

Turkey has one of the largest and richest reserves of zeolite in the world, including the Bigadic and Gordes reserves [11] [15]. Zeolite mineral formation is observed in nearly $2 / 3$ of the tuffs in Miocene piles in the Manisa-Gordes region. $80 \%$ of these tuffs are comprised of heulandite and clinoptilolite. These tuffs are located in the proximity Gordes county centre and they are placed as two levels lithostratigraphically. According to this, they are comprised of a Miocene residuum pile with a thickness of nearly $1000 \mathrm{~m}$, with one alluvial series at the bottom (bottom crude and fine grain units, blockstone-pebblestone sandstone and sandstone-pebble sandstone-local mudstone and shale) and a volcanoclastical lacustrine series at the top, which are inharmonious with the crystalline rocks of Menderes Massive and rock units of Izmir-Ankara Zone. Within this top series, at the bottom and the top (with 80 and $70 \mathrm{~m}$ of thickness respectively) are located two tuff series and an intercalated unit that is comprised of sandy, clayey, carbonated, tuffed and mixture of all of these. The tuff level possesses a rhyolite-rhyodacite character, the bottom tuffs are vitreous-crystal-partially lytic and lapilli ash-dust tuff arrayed from north to south. Top tuffs are vitreous-crystal, ash-dust tuffs. Phenocrystals are quartz, plagioclase (albite-oligoclase), sanidine 
Table 1. Structural features of Gordes clinoptilolites [13] [14].

\begin{tabular}{|c|c|}
\hline Chemical formulation & $\left(\mathrm{Na}_{0.5} \mathrm{~K}_{2.5}\right)\left(\mathrm{Ca}_{1.0} \mathrm{Mg}_{0.5}\right)\left(\mathrm{Al}_{6} \mathrm{Si}_{30}\right) \mathrm{O}_{72} \cdot 24 \mathrm{H}_{2} \mathrm{O}$ \\
\hline Mineralogical composition of raw material & $\begin{array}{c}\text { Clinoptilolite }(85 \%-90 \%)+\text { Simectite }(5 \%-6 \%) \\
\text { Opal-CT }(5-6)+\text { Quartz }(<3)\end{array}$ \\
\hline Clinoptilolite definition & $\begin{array}{l}\text { Rich in potassium, potassium, } \\
\text { calcium clinoptilolite }\end{array}$ \\
\hline Color & $\begin{array}{l}\text { Natural rock, white, beige, } \\
\text { light beige, almond green }\end{array}$ \\
\hline $\begin{array}{l}\text { Competence (According to Mohs } \\
\text { competence measurement) }\end{array}$ & 3 \\
\hline $\begin{array}{l}\text { Bulk density (according to granule bulk } \\
\text { that changes from dust to }<15 \mathrm{~mm} \text { ) }\end{array}$ & $500-1200 \mathrm{~kg} / \mathrm{cm}^{3}$ \\
\hline Bulk weight (dry) & $1.4-1.7 \mathrm{~g} / \mathrm{cm}^{3}$ \\
\hline Bulk weight (saturated) & $1.8-2.0 \mathrm{~g} / \mathrm{cm}^{3}$ \\
\hline Specific gravity & $2.1 \mathrm{~g} / \mathrm{cm}^{3}$ \\
\hline Visible porosity & $35 \%$ \\
\hline Water adsorption capacity & $135 \%$ \\
\hline Resistance in acidic and alkali environment & pH: $2-12$ \\
\hline Whiteness index & $64.8 \%-71.7 \%$ \\
\hline Surface area & $40.79 \mathrm{~m}^{2} / \mathrm{g}$ \\
\hline Thermal stability & Up to $750^{\circ} \mathrm{C}$ \\
\hline Pressure resistance & $10.10 \mathrm{MPa}$ \\
\hline Clinoptilolite crystal size & $5-15 \mu \mathrm{m}$ \\
\hline Average foramen radius & $0.041 \mu \mathrm{m}$ \\
\hline Water absorption by weight & $23 \%$ \\
\hline Ammonium $\left(\mathrm{NH}_{4}\right)$ ion changing capacity & $\begin{array}{c}\text { Interval: } 1.6-2.0 \mathrm{meq} / \mathrm{g} \\
\text { Average: } 1.8 \mathrm{meq} / \mathrm{g}\end{array}$ \\
\hline $\mathrm{CO}_{2}$ adsorption & $94 \mathrm{mg} \mathrm{CO}_{2} / \mathrm{g}$ \\
\hline Clinoptilolite morphology & Euhedral plate prism \\
\hline
\end{tabular}

and a low amount of biotites. Tuffs' authigenic minerals within the field are zeolites (mostly heulandite, clinoptilotes, locally analcime and rarely philippsite), silica minerals (opal-CT and quartz), clay minerals (smectites and 10 A clays; illitseladonite), K-feldspar and carbonate minerals (calcite and rarely dolomite). Diagenesis of volcanoclastical series have caused a widespread zeolitization and particularly heulandites-clinoptilolite type group minerals have developed in particularly tuffs and their glass parts, clearance, pumis fibre and all connective material. There are two types of group minerals, mainly clinoptilolite in the bottom tuffs and fully heulandite in the top tuffs [11] [16].

Experiments subject to this study are carried out upon the zeolite samples that were obtained from zeolite facilities still active in production in the ManisaGordes region. The Manisa-Gordes location map is illustrated in Figure 1. 


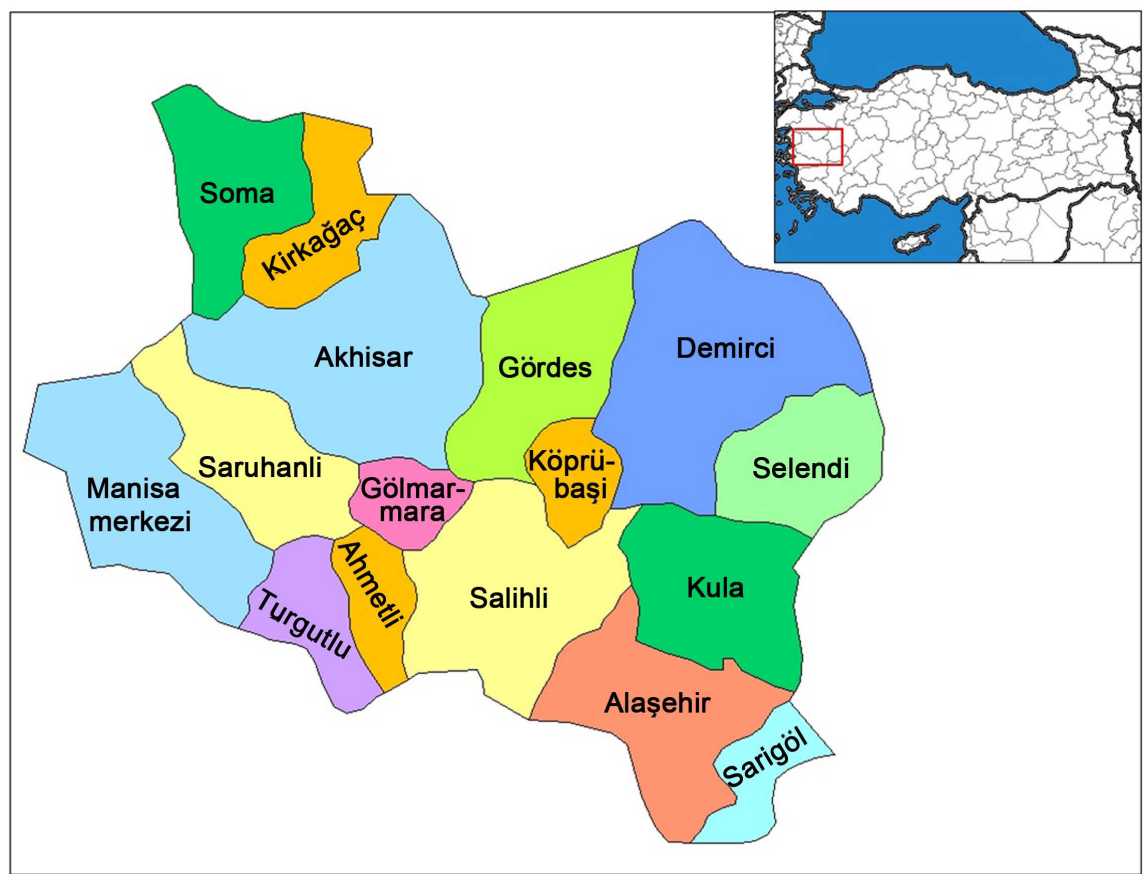

Figure 1. Turkey-Manisa-Gordes location map.

Belonging to these fields in the research study, zeolite was taken from this field according to the method.

\section{Utilization Areas of Zeolites}

The areas of usage for zeolites can be described under four main headings, which are pollution control, the energy sector, agriculture and stockbreeding. Applications for pollution control are; marginalizing heavy metals such as $\mathrm{Pb}, \mathrm{Cu}, \mathrm{Zn}$, $\mathrm{Cd}$ and $\mathrm{Hg}$ from industrial waste waters, marginalizing ammonium $\left(\mathrm{NH}_{4}^{+}\right)$, which has a toxic effect, from city waste waters and drinking water, lowering water hardness, regulating $\mathrm{pH}$-conductivity and raising the quality of drinking water, purifying chimney gases, cleaning up oil leaks, binding air pollutant gases such as $\mathrm{SO}_{2}, \mathrm{CO}, \mathrm{CO}_{2}, \mathrm{H}_{2} \mathrm{~S}, \mathrm{NH}_{3}, \mathrm{NO}_{x}$, garbage rubbish disposal areas, metallurgy applications, and marginalizing radioactive materials such as $\mathrm{Cs}, \mathrm{Sr}, \mathrm{Rb}$ from nuclear wastes. Zeolites' ion exchange, adsorption and molecular sieving properties are used for those applications. Applications regarding the naturalising and drying of natural gases, heat storage, oxygen generating, processing coal gases, separating industrial gas compounds such as $\mathrm{CH}_{4} / \mathrm{N}_{2}$ and $\mathrm{N}_{2} / \mathrm{H}_{2}$, oil refinement, and sun energy storage systems can be performed with the help of zeolites' ion exchange, adsorption, molecular sieving and catalyst properties [17] [18].

In agriculture and stockbreeding, zeolite, with its ion exchange, adsorption and molecular sieving properties, can be used as a fertiliser additive, in reclaiming soil by extracting excess water, conditioning soil for agriculture, preventing washing off of plant nutrients, stabilising $\mathrm{pH}$ in agricultural soil and regulating soil, as a carrier material for pesticides, moisture and insect control in grain 
stores, preventing ripening and hardening in fertilisers during storage, transferring nutrient ions on agricultural grounds, binding cations of unwanted heavy metals such as $\mathrm{Pb}, \mathrm{Cd}, \mathrm{Zn}$, and $\mathrm{Cu}$, as additive for animal feed, in cleaning ponds in fish farms in order to provide enough oxygen, preventing effluvia in barns, as cat soil, strengthening bones, enhancing egg and bone development, and bone meal applications.

In addition zeolite, with its ion exchange, adsorption and catalyst properties, is known to be used as a filling material in paper production, for seeking uranium beds in mining, as a light component element and cement additive in construction, in water culture applications, powder detergent applications, as a defroster on highways and in many other industries such as medicine [17] [18] [19] [20] [21].

\section{Applications Technologic Tests of Zeolite}

According to the work performed in taking into consideration the firing position and the colors; the zeolite sample shows us that it is unsuitable for use in the ceramic industry. Ceramic pre technological reviews on a zeolite sample are presented in Table 2.

The oil absorption test is made according to standard TS-2583 EN ISO 787-5/ December 1997 "The general test methods for pigments and fillers materials Part 5: Determination of the value of oil absorption" and the value of oil absorption is found to be $62 \mathrm{ml} / 100 \mathrm{~g}$.

Analysis of Whiteness is made using a "Minolta Chroma Meter CR300" device. Examination of the zeolite sample as cat litter is made according to standard TS-12131/February 1997. The standard used in the production of sepiolite-cat litter. The water absorption capacity is found as $64 \%$ and it has no mudding down and softening feature. Since the values of water absorption is less than $75 \%$, it is unsuitable for use as cat litter. The bleaching on the original form and activated form are determined as $1.12 \mathrm{~g}$ sample/g tonsil, $1.08 \mathrm{~g}$ sample/g tonsil respectively. Because samples in pieces with weighs are larger than 350 grams decompose in water, density and water absorption tests were made according to TS 699/January 1987. According to the "ASTM C493-98 Standard Test Method for Bulk Density and Porosity of Granular Refractory Materials by Mercury Displacement" the standard, porosity value of the zeolite sample has been identified as $1.19 \mathrm{gr} / \mathrm{cm}^{3}$.

Table 2. Ceramic pre technological reviews on zeolite sample.

\begin{tabular}{cccccc}
\hline $\begin{array}{c}\text { Original } \\
\text { Color and Status }\end{array}$ & $\begin{array}{c}\text { Dispersion } \\
\text { in the water }\end{array}$ & $\begin{array}{c}\text { Manual } \\
\text { Plasticity }\end{array}$ & $\begin{array}{c}\text { Reaction } \\
\text { dilute acid }\end{array}$ & $\begin{array}{c}\text { Firing on } \\
1150^{\circ} \mathrm{C}\end{array}$ & Firing on $1300^{\circ} \mathrm{C}$ \\
\hline $\begin{array}{c}\text { Cream in } \\
\text { pieces of large } \\
\text { and small }\end{array}$ & Yes ( Little) & $\begin{array}{c}\text { Little } \\
\text { plastic }\end{array}$ & No & $\begin{array}{c}\text { Beginning } \\
\text { of melting, } \\
\text { brown }\end{array}$ & $\begin{array}{c}\text { Melting in the } \\
\text { form of foaming, } \\
\text { greenish light brown }\end{array}$ \\
\hline
\end{tabular}


Because of the physical properties of the zeolite sample, the real density analysis could not be identified using device Accupyc Pycnometer 1330 Hc. In addition, water absorption tests could not be completed, due to the dispersion in water. The all of these results are presented in Table 3.

Determination of the original sample bleaching capability: After the sample was dried on $55^{\circ} \mathrm{C} \pm 5^{\circ} \mathrm{C}$ until constant mass, it was ground to pass through the 200 mesh (74 micron) bottom sieve. $1 \mathrm{~g}$ of the sample was put into the tube, 20 $\mathrm{ml}$ of oil-benzene mixture was added, and it was shaken for 10 minutes. After 24 hours, the value of $\% \mathrm{~T}$ (permittivity) was read on a calorimeter and the equivalence of tonsil was determined.

Determination of the activated sample bleaching capability: After the sample was dried on $55^{\circ} \mathrm{C} \pm 5^{\circ} \mathrm{C}$ until constant mass, it was ground to pass through the 200 mesh (74 mikron) bottom sieve. $100 \mathrm{ml}$ of distilled water was placed in accordance beaker and $20 \mathrm{~g}$ of the sample was added. This mixture was then mixed thoroughly with begets and $12.5 \mathrm{ml}, 98 \%$ concentrated $\mathrm{H}_{2} \mathrm{SO}_{4}$ was added. It was kept for 1.5 hours on a hot plate at boiling point. After the boiling time, the sample was left for 24 hours. Afterwards, the sample under vacuum was filtered until there was no acid in permeate and left to dry. The sample in the form of a dried cake was ground again and the bleaching process was applied to the original sample again. Chemical analysis results of the sample are presented in Table 4.

Table 3. Technologic tests results of zeolite.

\begin{tabular}{|c|c|c|}
\hline \multirow{5}{*}{$\begin{array}{c}\text { Ceramic } \\
\text { pre-technological } \\
\text { reviews on } \\
\text { zeolite sample }\end{array}$} & Original Color and Status & $\begin{array}{l}\text { Cream in pieces } \\
\text { of large and small }\end{array}$ \\
\hline & Dispersion in the water & Yes (Little) \\
\hline & Manual Plasticity & Little plastic \\
\hline & Reaction dilute acid & No \\
\hline & Firing on $1150^{\circ} \mathrm{C}$ & Beginning of melting, brown \\
\hline \multirow{3}{*}{ Value of oil absorption } & Firing on $1300^{\circ} \mathrm{C}$ & $\begin{array}{l}\text { Melting in the form of } \\
\text { foaming, greenish light brown }\end{array}$ \\
\hline & Value of oil absorption, (ml/100g) & 62 \\
\hline & Percentage of whiteness, $\mathrm{P},(\%)$ & 76.65 \\
\hline \multirow{3}{*}{$\begin{array}{l}\text { Whiteness } \\
\text { measurements }\end{array}$} & Measurement of Whiteness, L, (\%) & 90.15 \\
\hline & a & -1.27 \\
\hline & $\mathrm{b}$ & 6.32 \\
\hline \multirow{2}{*}{$\begin{array}{l}\text { Examination the } \\
\text { zeolite sample } \\
\text { as cat litter }\end{array}$} & Water absorption capacity, (\%) & 64 \\
\hline & $\begin{array}{l}\text { Mudding down and } \\
\text { softening feature }\end{array}$ & No \\
\hline \multirow{2}{*}{$\begin{array}{c}\text { Determination of } \\
\text { bleaching capability }\end{array}$} & $\begin{array}{l}\text { Bleaching on original form, } \\
\text { g sample/g tonsil }\end{array}$ & 1.12 \\
\hline & $\begin{array}{l}\text { Bleaching on activated form, } \\
\text { g sample/g tonsil }\end{array}$ & 1.08 \\
\hline $\begin{array}{l}\text { Porosity values } \\
\text { of zeolite sample }\end{array}$ & Density $\left(\mathrm{gr} / \mathrm{cm}^{3}\right)$ & 1.19 \\
\hline
\end{tabular}


Table 4. Chemical analysis results of the sample.

\begin{tabular}{cc}
\hline Analysis & Test Results (\%) \\
$\mathrm{Na}_{2} \mathrm{O}$ & 0.5 \\
$\mathrm{MgO}$ & 0.9 \\
$\mathrm{Al}_{2} \mathrm{O}_{3}$ & 10.7 \\
$\mathrm{SiO}_{2}$ & 69.7 \\
$\mathrm{P}_{2} \mathrm{O}_{5}$ & $<0.1$ \\
$\mathrm{~K}_{2} \mathrm{O}$ & 3.9 \\
$\mathrm{CaO}$ & 2.6 \\
$\mathrm{TiO}_{2}$ & 0.1 \\
$\mathrm{MnO}$ & $<0.1$ \\
$\mathrm{Fe}_{2} \mathrm{O}_{3}$ & 1.2 \\
$\mathrm{~A} . \mathrm{Za}\left(1050^{\circ} \mathrm{C}\right)$ & 9.15 \\
\hline
\end{tabular}

\section{X-Ray Analyses of the Zeolite Sample}

The zeolite sample was subjected to X-Ray diffractometer studies. Which diffraction distribution corresponds to which $2 \theta$ was defined by the peaks in the continuous spectrum by the X-Ray diffractometer shoots. The DHKL distances and reflection intensities which corresponds to each $2 \theta$ that provides Bragg diffraction condition $(\mathrm{n} \lambda=2 \mathrm{~d} \operatorname{Sin} \theta)$ were detected from catalogues. In order to define the phases that the peaks belong to, diffraction indexes created by American Society for Testing Material (ASTM) were used. Those standardised cards were used to define the phases that have a crystalline formation in the samples. X-Ray diffractometer parameters used in the experiments are Heulandite, Clinoptilolite as diffraction.

In the X-Ray studies defined according to the conditions above, zeolite has the same properties and includes both Heulandite and Clinoptilolite. In Table 5, the detected mineral structure according to the X-Ray analysis is provided. Heulandite properties are higher than Clinoptilolite in the zeolite sample. In addition, quartz, feldspar and biotite minerals were also detected with X-Ray.

The result of XRD analysis carried out between $2^{\circ}-70^{\circ}$ by a Philips $\mathrm{PW}$ 3710/1830 XRD analyser with a Cu X-ray tube is presented below in Figure 2. There are zeolite group minerals (heulandite-clinoptiolite, very little analcime ASTM No: 41 - 1478), feldspar group mineral, very little mica-group minerals, very little group of mixed layer clay minerals, very little amphibole group mineral, very little quartz (ASTM No: 33 - 1161), very little kaolin group clay mineral, very little calcite (ASTM No: 5 - 585), amorphous material in this zeolite sample.

\section{Microscopic Analysis of the Zeolite Sample}

Analysis results of the experimental subject of zeolite samples (mass and grain) 


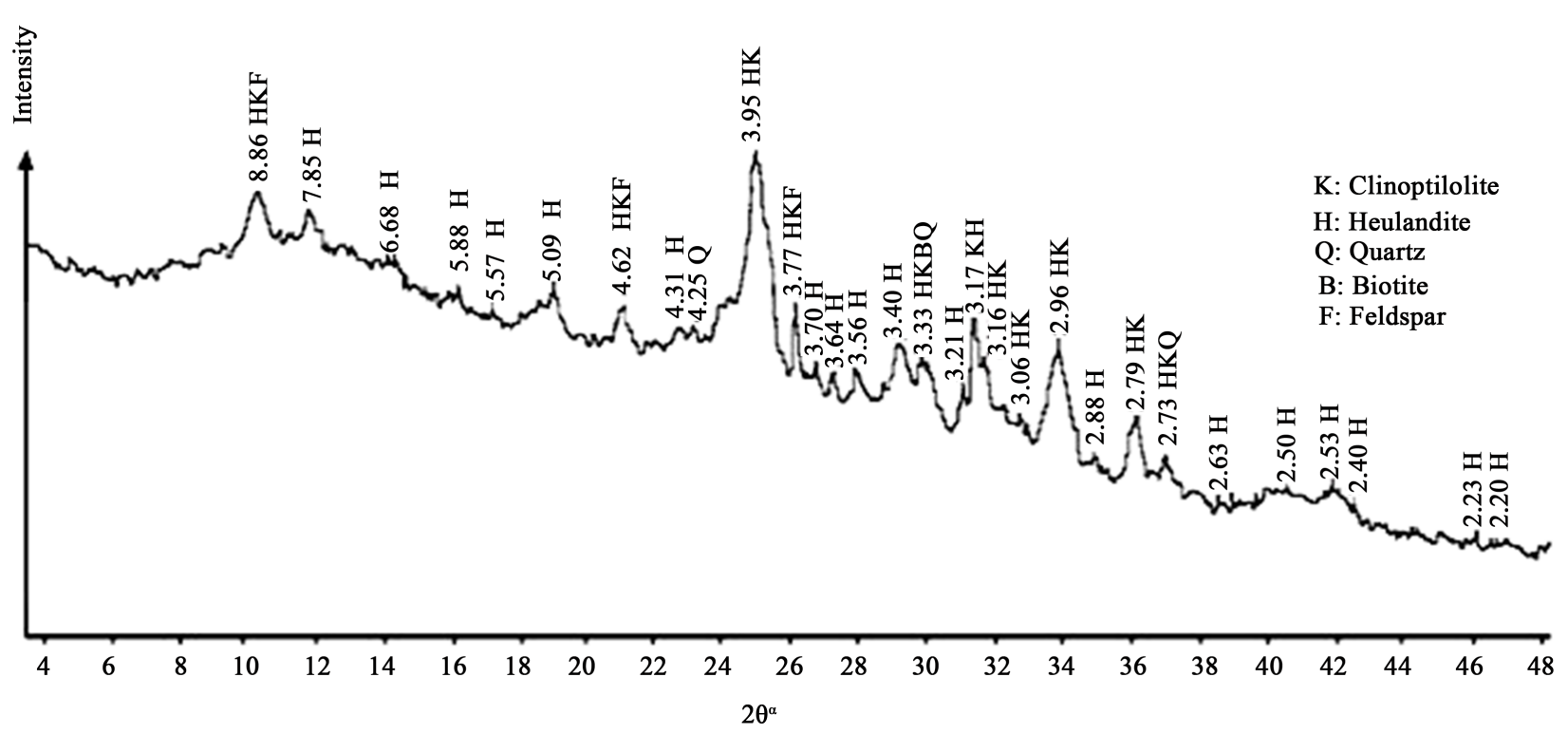

Figure 2. X-ray analysis chart.

Table 5. X-Ray diffractometer parameters.

\begin{tabular}{lccccccccccccc}
\hline Measurement & Tube & Kv & Ma & Crystal & Detector & Silit & Filter & GPS & Time & $\begin{array}{c}\text { Scan rate } \\
(\% / m i n .)\end{array}$ & $\begin{array}{c}\text { Card rate } \\
(\mathrm{mm} / \mathrm{min} .)\end{array}$ \\
\hline Spectrometer & $\mathrm{Cu}$ & 32 & 22 & - & $\mathrm{GM}$ & - & $\mathrm{Ni}$ & 1.103 & 2 & 2 & 20 \\
\hline
\end{tabular}

by Olympus SZx16 type binocular microscope are presented below. Microscopic images of zeolite sample can be seen in Figures 3(a)-(e) Zeolite's binocular microscopic images, as can be seen in Figure 3(a), show the base surface under white clean zeolite minerals and partial biotite (mica) and ferrous oxide contamination can be observed $(5 x)$.

Zeolite's binocular microscopic images, as can be seen in Figure 3(b), show ferrous oxide introvisions, in other words, entries with the sizes of approximately $959.99 \mu \mathrm{m}-589.74 \mu \mathrm{m}$ into the zeolite $(5 \times)$. Zeolite is processed in usage as either $(+)$ or $(-)$, depending on the desire for iron or not. Only in the very high quality zeolite productions, washing or acid cleaning operations can be possible under these sizes.

Zeolite's binocular microscopic images, as can be seen in Figure 3(c), under microscopic visual clean zeolite grains are observed as $95 \%$ in the size of approximately $0.99 \times 1.52 \mathrm{~mm}$ of broken zeolite sample $(2.5 \times)$. However, the grain is observed and imaged as clamped together as biotite grain with the size of 200 $\mu \mathrm{m}$.

Zeolite's binocular microscopic images in the grain size of $-1.5 \mathrm{~mm}$, as can be seen in Figure 3(d) in the observation in which the zeolite's broken grain material under the size of $1 \times 1.5 \mathrm{~mm}$ was bated under the microscope, it was seen that besides the free zeolite grains, ferrous oxide mineral daubing (yellowish, reddish) and partially free and mostly pointed clamped biotite grains were 


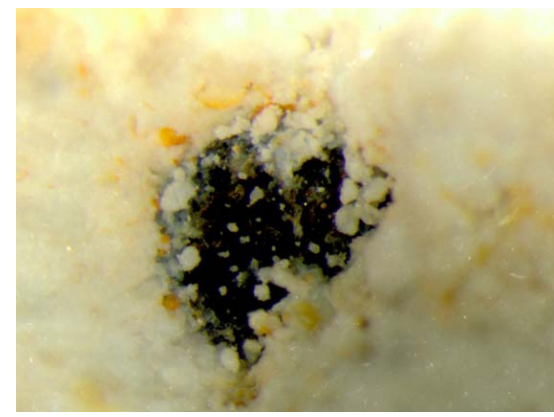

(a)

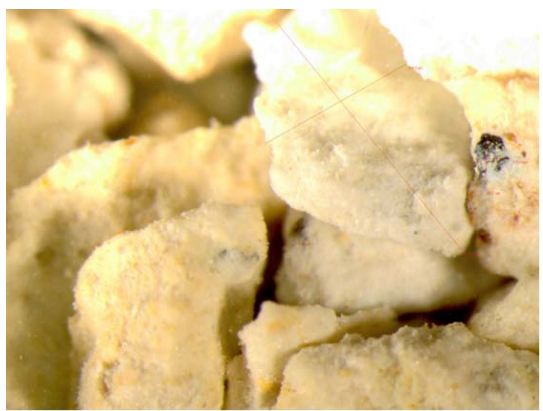

(c)

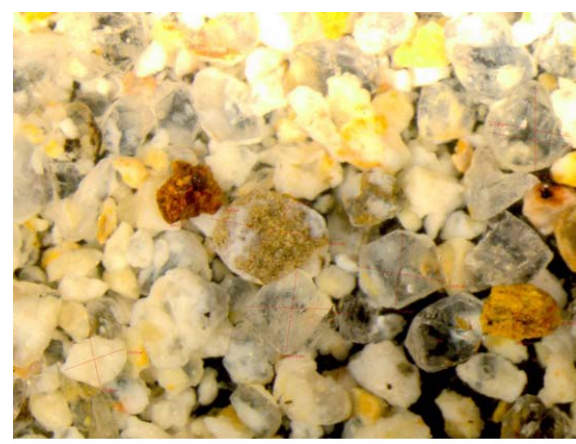

(e)

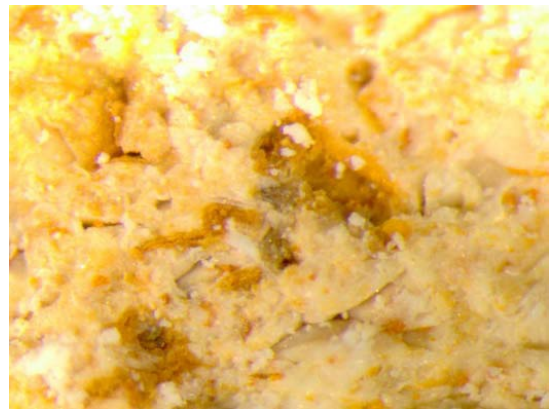

(b)

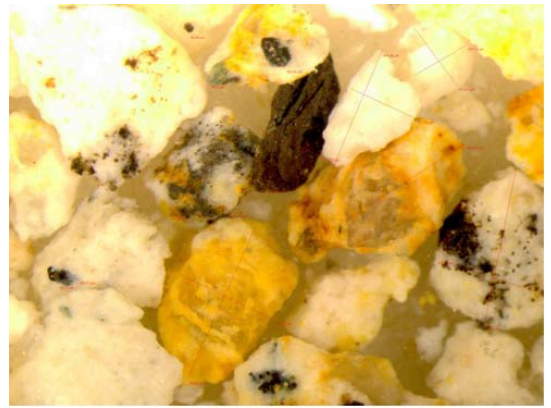

(d)

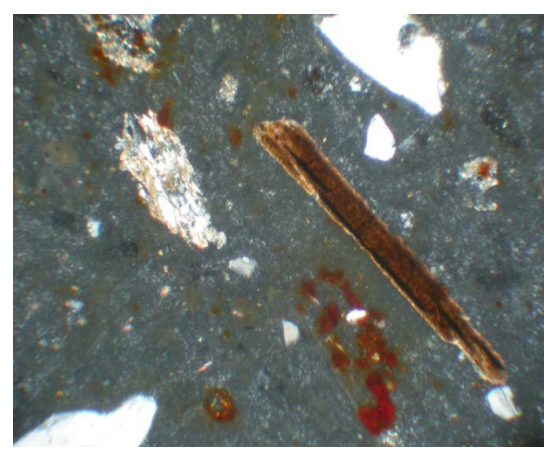

(f)

Figure 3. Microscopic images of zeolite samples: (a) Image of a piece of sample; (b) Image of sample on microscope; (c) Introvisions of iron oxide $(959.99 \mu \mathrm{m}-589.74 \mu \mathrm{m})$; (d) Sight of sample under $(0.99 \times 1.52 \mathrm{~mm})$; (e) Image of zeolite sample under $1.5 \mathrm{~mm}$; (f) A thin section sample [18].

observed gravimetrically under the R04 visuals of nearly $20 \%(1.5 \times)$. This event points out that the zeolite is contaminated. According to the usage areas, this type of zeolite can be selectively broken under $1 \mathrm{~mm}$ or $0.5 \mathrm{~mm}$ and converted to a cleaner product via enrichment according to density. Waste and side products that emerged after this enrichment process can also be used according to the consumption, for example in soil improvement.

Zeolite's binocular microscopic images in the grain size of $-1.5 \mathrm{~mm}$, as can be seen in Figure 3(c). is bated into the zeolite sample, it is seen and observed that quartz and ferrous oxide and other biotite-clamped grains are intensified because they are denser than zeolite, and if a clean process is performed among them, for example planar attraction, cleaner crystal quartz can be obtained 
$(1.25 \times)$. It is measured with a digital camera that mentioned crystal quartz is in the size of $433-373 \mu$, tracked by RO5. If this sample A is selectively and protectively disintegrated under $400 \mu$, for example subjected to dry or damp density dependent enrichment, followed by magnetic enrichment, it is observed that clean crystal quartz can be obtained. These obtained quartzes can be used in the glass or ceramic sector.

Images obtained by the microscopic analyses carried out on the thin sections prepared from a zeolite sample are presented in Figure 3(f). According to these images, the zeolite sample contains trace minerals such as biotite, metamorphic rock remnants, iron, quartz, plagioclase (feldspar), as seen in Figure 3(f).

In the microscopic analyses, the first degree of the softest zeolite minerals and clay show fine grain sized collapse, third degree quartz are in the largest sizes, the middle degree solid biotite and ferrous oxide are in the second degree. If extremely thin sized material is required, the surface of the quartz below $500 \mu$ will be free and biotites will leave the surface. If $99 \%$ of mineral purity, high quality zeolite is required, it is concluded that the iron, hematite and biotites, which are present in trace amounts within the structure, can be removed by magnetic separation. In the broken grain material below the $1 \times 1.5 \mathrm{~mm}$ zeolite sample size, ferrous oxide mineral daubing (yellowish, reddish) and partially free and mostly pointed clamped biotite grains are observed. This shows that the zeolite is contaminated. According to the request of the usage fields, this type of zeolite can be selectively disintegrated below $1 \mathrm{~mm}$ or $0.5 \mathrm{~mm}$ and can be subjected to density-dependent enrichment in order to obtain a cleaner product. It is observed and imaged that, the zeolite sample has more intense quartz and ferrous oxide and grains clamped with other biotite, compared to zeolite, and it is possible via a clean process, for example surface attraction to obtain cleaner crystal quartz. Crystal quartzes are in the sizes of $433-373 \mu$ and it is observed that if the zeolite sample is subjected to selective and protective disintegration under $400 \mu$ and enriched according to dry or damp density, followed by a magnetic enrichment, clean crystal quartzes can be obtained. The obtained quartz can be used in the glass or ceramic sector. It is concluded that zeolite mineral is relatively clean, but for very high quality production, it should be downsized to below $150 \mu$ and the contaminating minerals must go free and with a dry or damp environment enrichment, it is possible to obtain a multi quality zeolite concentrate. It has been proven with microscopic analysis and in digital media that clean zeolite grains mostly go free in a wide spectrum from $600 \mu$ to $300 \mu$ and even thinner. If it is milled down to these sizes and enriched in a dry and damp environment quality zeolite concentrate production will be possible. Within the scope of this study, according to the microscopic analyses results carried out towards the assessment of the structural features of Manisa Gordes zeolites, it should be considered that structural contaminant gang minerals must be removed and quality zeolite should be obtained with ore preparation and enrichment methods. Based on the ore formation, realisation of selective mining should be taken into consideration in zeolite production. Environmental contamination should be avoided 
and preventive production measures should be taken on this matter (for example: dust suppression curtains should be used.

Morphological analyses were carried out using SEM. SEM observations showed the presence of micro-particles in the shape of smooth surface. Displays of an electron microscopy of zeolite minerals are shown in Figure 4.

\section{Conclusions}

In Turkey, clinoptilolites are generally used in agriculture and stockbreeding. The clinoptilolite group of zeolites with $85 \%$ purity has many areas of usage, according to their size. In this case, products gathered from primary crushing

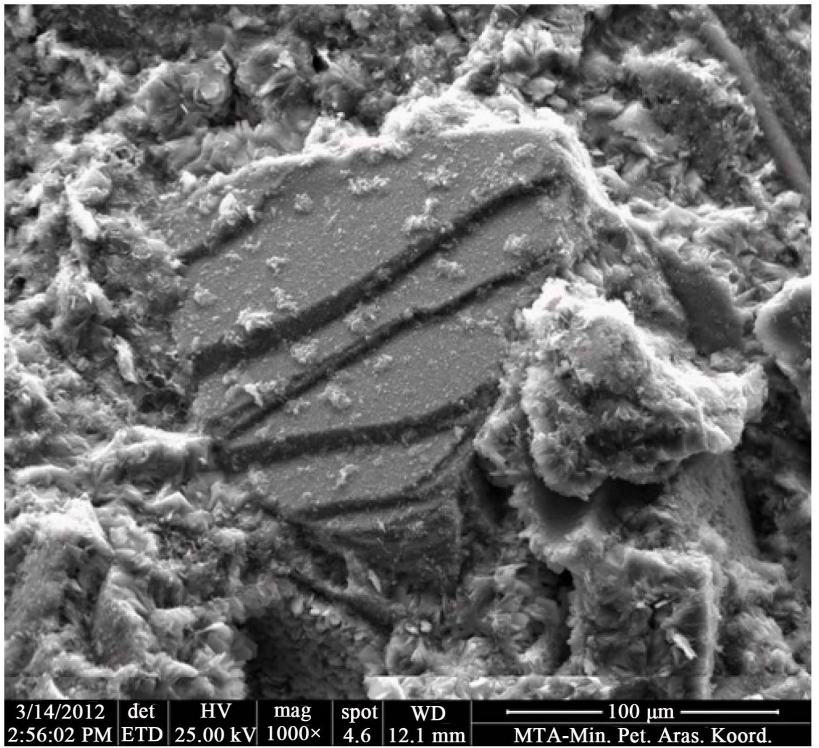

(a)

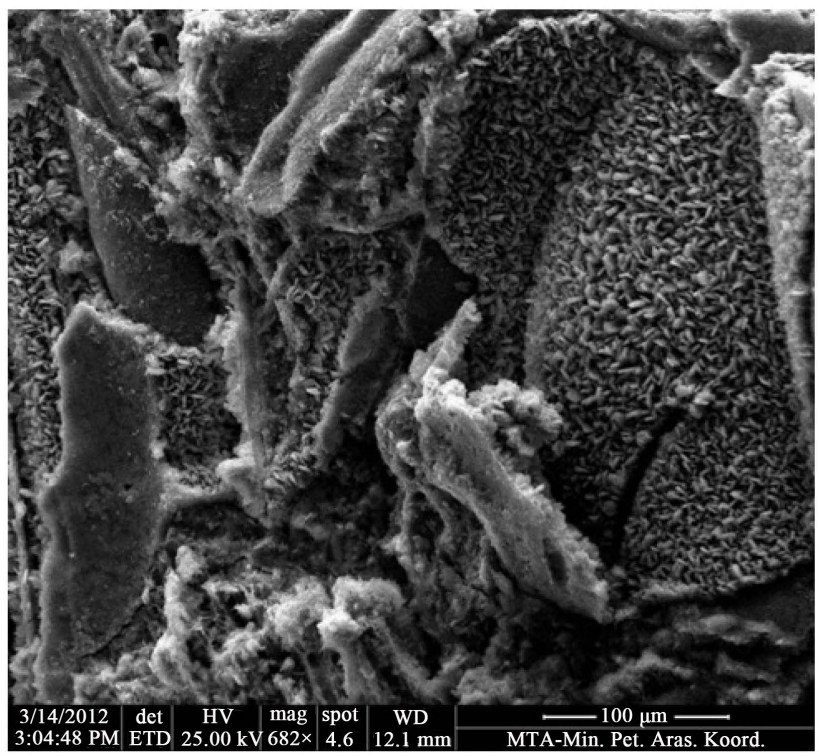

(c)

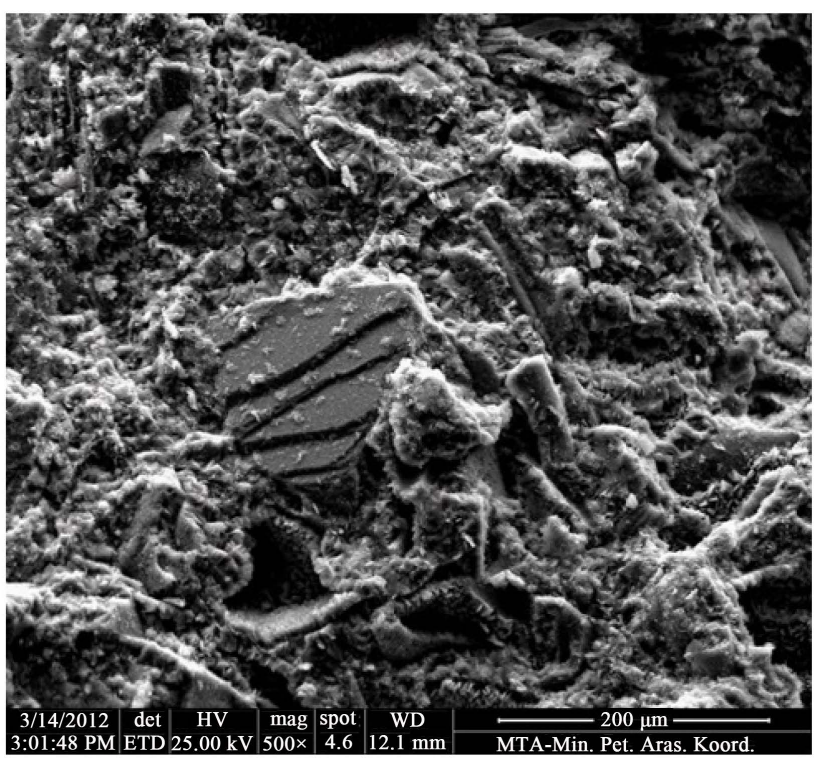

(b)

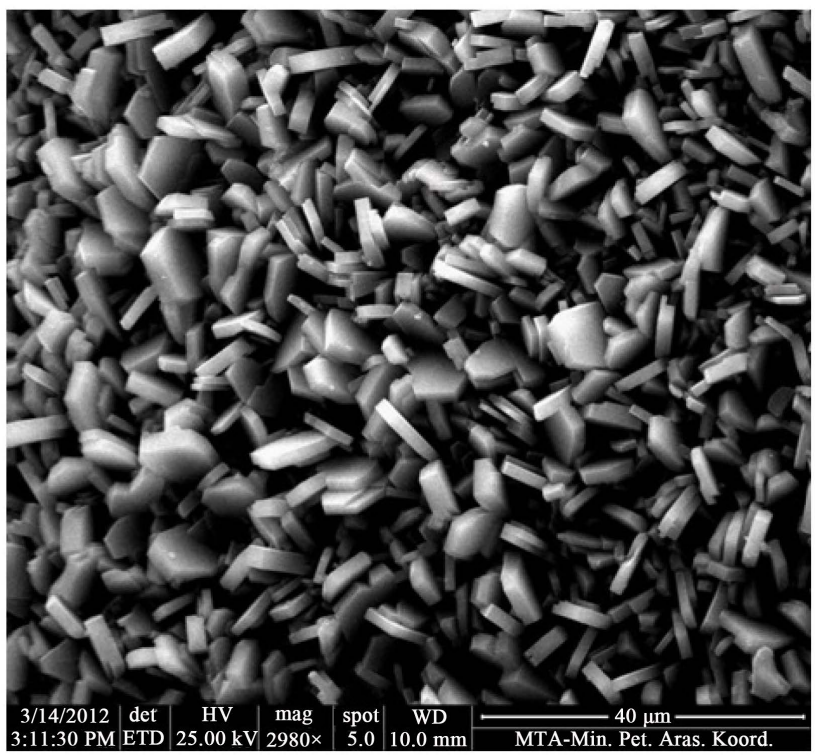

(d)

Figure 4. Displays of scanning electron microscopy. 
can be used in gas purification. Products under $5 \mathrm{~mm}$ and gathered from secondary crushing can be used in water filtering (filtration) or put into use as animal mat or fertiliser additive. These processes generally use zeolites of $2-5 \mathrm{~mm}$. The zeolites used in this study should be used for industrial areas and the improvement of agricultural lands. Zeolites that show efficiency in agricultural production and are needed to produce economic efficiency in water and fertiliser are carried out using consciously. Especially in Turkey, soil pollution created by immoderate use of water and fertiliser is eliminated by the use of zeolites. They are used in the prevention of heavy metal pollution such as $\mathrm{Pb}, \mathrm{Cu}, \mathrm{Zn}, \mathrm{Cd}$ and $\mathrm{Hg}$, which pollute the environment via industrial wastes in solid, liquid, gas. The use of zeolite via high adsorption force will contribute to preventing toxic contamination created by heavy traffic caused by heavy metal gases $(\mathrm{Pb}, \mathrm{Cu}, \mathrm{Zn}$, $\mathrm{Cd}$ and $\mathrm{Hg}$ ) nowadays and achieve a healthy environment for both people and cities. Therefore, Gördes zeolites should be considered for this purpose. The investigations indicate that it is also used as an additive for cement, which is more economical with lightweight structural elements in the construction industry, which can be done with zeolite. According to the results of microscopic examination in order to identify the structural features of Manisa Gordes zeolite, removing polluting gangue minerals in the structure and production of more quality zeolite provided by mineral processing and beneficiation methods should be considered. Based on the formation of ore, selective mining for production of zeolite should be considered. We should avoid environmental pollution and precautions should be taken for this required production (for instance, using a dust holding curtain).

\section{References}

[1] Bowman, R.S., Haggerty, G.M., Huddleston, R.G., Neel, D. and Flynn, M.M. (1995) Sorption of Nonpolar Organic Compounds, Inorganic Cations, and İnorganic Oxyanions by Surfactant-Modified Zeolite. In: Sabatini, D.A., Knox, R.C. and Harwell, J.H., Eds., Surfactant-Enhanced Subsurface Remediation, ACS Symposium Series, Vol. 594, 54-64. https://doi.org/10.1021/bk-1995-0594.ch005

[2] Jacobs, P.H. and Förstner, U. (1999) Concept of Subaqueous Capping of Contaminated Sediments with Active Barrier Systems (abs) Using Natural and Modified Zeolites. Water Research, 33, 2083. https://doi.org/10.1016/S0043-1354(98)00432-1

[3] Mier, M.V., Callejas, R.L., Gehr, R., Cisneros, B.E.J. and Alvarez, P.J.J. (2001) Heavy Metal Removal with Mexican Clinoptilolite: Multi-Component İonic Exchange. Water Research, 35, 373. https://doi.org/10.1016/S0043-1354(00)00270-0

[4] Bauman, M., Mesaric, M., Ribar, S., Maric, V. and Tudja, M. (2001) Natural Zeolite Clinoptilolite Increases the Concentrations of Sphingoid Bases in the Yeast Yarrowia Lipolytica. Journal of Basic Microbiology, 41, 7-16. https://doi.org/10.1002/1521-4028(200103)41:1<7::AID-JOBM7>3.0.CO;2-Z

[5] Breck, D.W. (1974) Zeolites Molecular Sieves. John Wiley \& Sons, New York, 771.

[6] Ceyhan, T., Tatlier, M. and Akçakaya, H. (2007) In Vitro Evaluation of the Use of Zeolites as Biomaterials: Effects on Simulated Body Fluid and Two Types of Cells. Journal of Materials Science: Materials in Medicine, 18, 1557-1562. 
https://doi.org/10.1007/s10856-007-3049-y

[7] Kurama, H. (1999) The Effects of Zeolite on Germination of Tritikum Sativum (Wheat), and Cucumis Sativus (Cucumber). Plant Growth and Development, 8, 21.

[8] Tosun, A. (2005) Effects of Addition of Some Compounds on Ethanol Production from Synthetic Molasses by Fermentation. Doktoral Thesis. Gazi University, Ankara.

[9] Bilgin, Ö. and Köktürk, U. (2010) Raw Material Properties of Gordes Zeolite Ores. The Journal of Ore Dressing, 11, 34-45.

[10] Sheppard, R.A. (1973) Zeolites in Sedimentary Deposits of the United States-A Review. Molecular Sieve Zeolites-I. Advances in Chemistry, 101, 279-310.

[11] Esenli, F. (1992) Geological, Mineralogical and Geochemical İnvestigation of Neogene Series and Zeolization in the Vicinity of Gördes. Doktoral Thesis, Istanbul Technical University, Istanbul, 250.

[12] Boles, J.R. (1972) Composition Optical Properties, Cell Dimensions \& Thermal Stability of Some Heulandite Group Zeolites. American Mineralogist, 57, 1463-1493.

[13] Ozaydin, S. (2005) Utilization Opportunities of Clinoptilolite in Turkey and Determination of Some Thermal Properties of Gordes Clinoptilolite. Doktoral Thesis, Ege University, Izmir, 150.

[14] Esenli, F. and Benli, B. (2004) Mining Products Mineralogical-Petrographic Investigation Report. ITU Mining Faculty, n: B.30.2.ITU.0.52.02.02: 28.

[15] Ataman, G. (1997) Formation of Zeolites in Western Anatolia. Earth Science, 3, 8.

[16] Esenli, F. and Özpeker, I. (1993) Zeolitic of the Neogene Basin around Gördes Diagenesis and Mineralogy of Hoylandite-Clinoptiolites. Convention Presentation Essays Book, p. 63, February 15-19 in Ankara.

[17] (2017) http://manisa-resimleri.blogspot.com.tr/2008/05/manisa-ileleri-haritas.html

[18] Bilgin, O. (2009) Investigation of the Raw Material Properties of Gordes Zeolite Ores and Searching Their Usability in Different Sectors. Doktoral Thesis, 9 Eylul University, Izmir, 200.

[19] (2001) The Reports of Special Ad Hoc Committee of the Eighth Five-Year Development Plan. (Mica-Zeolite-Meerschaum), Working Group Report, Ministry of Development, Ankara, Turkey.

http://www3.kalkinma.gov.tr/DocObjects/Download/3476/oik630.pdf

[20] Yörükoğulları, E. (2005) The Use of Natural Zeolites as a Solvent Ice/Snow on Roads. Mining Bulletin, 40-42.

[21] Bilgin, O. (2014) Natural Zeolite Minerals as Storage of Solar Energy. International Journal of Engineering Research \& Technology, 3. 
Submit or recommend next manuscript to SCIRP and we will provide best service for you:

Accepting pre-submission inquiries through Email, Facebook, LinkedIn, Twitter, etc. A wide selection of journals (inclusive of 9 subjects, more than 200 journals)

Providing 24-hour high-quality service

User-friendly online submission system

Fair and swift peer-review system

Efficient typesetting and proofreading procedure

Display of the result of downloads and visits, as well as the number of cited articles Maximum dissemination of your research work

Submit your manuscript at: http://papersubmission.scirp.org/

Or contact jmmce@scirp.org 